\title{
CCXXI. MOLUKKEN.
}

1657. $\left.{ }^{1}\right)$

Ook met Ticlore was de verhouding in den tijd van De Vlamingh's superintendentie wisselend gebleven, iets wat door de aanwezigheid der Spanjaarden op dit eiland nog ingewikkelder werd gemaakt. Niettegenstaande den vredestoestand tusschen de Spanjaarden en de Nederlanden in Europa, was men in de Molukken niet in bijzonder goede relatie. Daar Tidore met onze inlandsche vijanden gemeene zaak maakte, brak in 1653 de oorlog uit, welke in 1654 weder eindigde, maar al spoedig weder werd voortgezet, tot in 1657 opnieuw een verdrag werd gesloten met den nieuwen sultan, Saif Oeddin. Diens voorganger stierf 7 Jan. 1657 en de nieuwe Sultan was een creatuur der O. I. C., die met behulp der Ternatanen onder Nederlandschen invloed het sultanaat verwierf, (Valentijn, Molukse Zaaken, bldz. 305, v.v. - Dassen, Molukken, bldz. 125. - Bokemeijer, S. 217 ff en Anhang, - Realia, III, bldz. 274 onder 2 November 1655).

Artijculen ende voorwaerden, waerop den grootmaghtigen Saifoedin, Coninck der Tijdoreesen, met sijn rijcxraedt voor hem, zijne onderdanen ende naercomelingen ter eenre ende den E. Sijmon Cos, ${ }^{2}$ ) gouverneur wegens den Nederlantsen Staet over de eijlanden Molucco, op approbatie van d'E. Heer Gouverneur Generael en d'E. Heeren Raden van Jndia, ${ }^{3}$ ) ter andere zijde geaccordeert ende overeen gecomen zijn, als namentlijck:

Dat wij, Coninck van Tijdor, alle de nagelen ende notebomen jegenwoordigh op 't eijlant Tijdore groeijende, datelijck zonder vertoeven ten bijzijn van die geene wien den Heer Gouverneur daer bij zall believen te ordonneeren, zullen omslaen, ruineeren en verderven ende tot die geene, welke te naer aen der vijanden ${ }^{4}$ ) sterckten zijn

1) Uit het Contractboek. De juiste datum van deze overeenkomst is mij niet bekend geworden. De kopiist heeft blijkbaar eerst gemeend, dat zij tot 1656 behoorde, want in het Contract vindt men hierbij de marginale aanteekening: „Nota dit contract is eijgenlijck aengegaen in 't jaer 1657". Trouwens, sultan Saif Oeddin, die de overeenkomst sloot, is eerst in 1657 „Coninck der Tijdoreezen” geworden. (Stokvis, Manuel, I, p. 391. - Bokemeijer, S. 247).

2) Opgevolgd (1656) aan Hustaerdt, die gouverneur van Ambon werd (Valentijn, Molukse Zaaken, bldz. 323; Bokemeijer, S. CXXXVI).

3) Aan deze ,approbatie" behoefde natuurlijk geen twijfel te bestaan. Nu ook Tidore's vorst het hoofd boog en de nagelcultuur in zijn rijk uitroeide, was het hoofddoel der Moluksche en Ambonsche politiek der O. I. C. bereikt: de nagelcultuur was nu beperkt tot Ambon en de Oeliasers (Vgl. Bokemeijer, S. CXXV, CXXXIV).

4) Spanjaarden. 
staende om gevoeghlijcx zonder hullpe te connen werden vernietight, zullen wij zodanige weghwijzers ende volck toe contribueeren, den Gouverneur willende de zijne daerbij doen, als eenighzints vermogen uijt te setten en comen te vereijschen.

De nagelen eenmaell wesende uijtgeroeijt, sullen niet gedoogen dat die weder werden aengeplant, $t$ zij op Tijclore selffs of $f$ eenige andere onderhorige landen en zoo naermaells eenige moghten werden gevonden weder uitgesproten offte over $t$ hoofft gesien te zijn, nemen wij aen die op stont te vernietegen, sullen tot dien eijnde de plaetsen waer desellve bomen gestaen hebben off gedaght werden te konnen zijn, jaerlijckx ter degen visiteeren ende besoeken, ook swaerlijck straffen die geene, wier bevonden werden eenige dersellver te hebben aengehouden.

Dat wij ons met geenige natien, $\mathrm{t} z \mathrm{ij}$ wier het soude mogen wesen, in vruntschap zullen verbinden en op dat sulx buijten bedencken blijven magh, sullen wij genege buijtenlanders, well verstaende die met $^{1}$ ) zijn onderdanen van de Moluxe coningen, op onze stranden gedoogen maer affwijsen, ten ware die expresse Nederlandtse pascedullen daer toe waren verleent. Ook sullen wij geensints met onze vaertuijgen buijten 't Moluxe district ende landen, onsen croon onderdanigh, vermogen te varen, sonder allvooren speciaell consent in geschriffte van den Nederlandsen Gouverneur te hebben becomen.

Generalijck ingageeren wij ons zoodanigh aen d'E. Comp ${ }^{c}$, dat wij willen zijn vrunden van hare vrunden ende vijanden van wien sij haten en beoorlogen, tot welckers uijtvoeringe wij beloven onse crijgsmaghten sodanigh te contribueeren als den staet ende redelijckheijt vereijssen zall.

Den gouverneur beloofft aen d'andere zijde, haer in haer religie en gelooff niet te turbeeren, bespotten off hoon aen te laten doen, veell min dwingen de Christelijcke aen te nemen, maer haer zodanigh laten gewerden, als ijder zall meenen voor zijne zaligheijt mits ${ }^{2}$ ) te zijn.

Ende zoo lange sij dese gehoorsaemheijt en conditien voorgemelt well naercomen ende in continueeren en anders niet, beloof $\mathrm{ft}$ den

1) Schrijffout voor "niet".

2) Schrijffout voor "nut". 
Gouverneur aen haer te betalen jaerlijcx een somme van drij duijsent realen tot 48 stuijvers ijder $^{1}$ ) zonder meer, beginnende met dit jaer ende soo vervollgende; als schip off schepen van Batavia zullen zijn gearrijveerdt, ook haer te beschermen zoo veell mogelijck naer tijts gelegentheijt tegen alle vijanden die haer of fte hare goederen sullen traghten te bespringen en belagen.

De volckeren, die van de vijanden overcomen, sullen haer mogen vervoegen onder wiens gehoorsaemheijt sij willen, all ware het ook dat ze te voren onderdanen van den Tijdoresen croon off van d'E. Comp $^{e}$ waren geweesst, sonder dat ze naermaells daer weder uijt getrocken zullen mogen werden, tot welcken eijnde die bij den Nederlantsen gebieder sullen werden gebraght en affgevraeght de hoedanigh $^{t}$ haerder will, onder welcke de overgelopen slaven, die hare oude meesters weder toegevoeght off de waerde daervoor betaallt zall werden, niet sullen zijn gereekent. ${ }^{2}$ )

\title{
CCXXII. VENGURLA-KANARA.
}

\begin{abstract}
Maart 1657. ${ }^{3}$ )
Met Kanara aan de Westkust van Voor-Indië (North- en South-Kanara) moet hier niet verward worden Kanara of Carnatica aan de Oostkust (Nortin Arcot). Ook Kanara aan de Westkust was een brokstuk, overgebleven van het Hindoe rijk Vijaijanagar, voor de Mohammedaansche aanvallen bezweken in 1565 (slag bij Talikota) (vgl. Corp. Dipl., I, p. 83 en de daar aangehaalde litteratuur, Hunter, Gazetteer, new edition, XIV, p. 343, 356; Sewell, Forgotten Empire, p. 214 ff, Rice, Kanarese litcrature, second edition, p. 12). Dat ook dit Kanara met Carnatica werd vereenzelvigd, moge blijken uit Dagh-Register 1656-1657, bldz. 164.4) Ofschoon meer dan eens pogingen waren aangewend door den vorst van Kanara, handelsbetrekkingen met de $\mathrm{O}$. I. C. via Vengurla aan te knoopen, was dit tot nog toe nog steeds mislukt. In 1657 kwam men tot een verdrag of contract met ,'t korenrijk Canara", „een overvloedig land van rijst" (Valentijn, Ceijlon, bldz. 162, 244).
\end{abstract}

1) Te Batavia „,doet 1 Reael 48 lighte of 38 Hollandsche stuijvers" (Uiitreckening, bldz. 3). Deze waarde is blijkbaar in dit contract gevolgd.

2) De onderteekening ontbreekt.

3) Uit het Contractboek.

4) Vgl. ook Hobson-Jobson, sub vocibus Canara en Camatica (pp. 152 ff en $164 \mathrm{ff})$. 